\title{
Trying to Assess the Quality of Macroeconomic Data - the Case of Swiss Labour Productivity Growth as an Example
}

\section{Working Paper}

Author(s):

Hartwig, Jochen

Publication date:

2007-09

Permanent link:

https://doi.org/10.3929/ethz-a-005431034

Rights / license:

In Copyright - Non-Commercial Use Permitted

Originally published in:

KOF Working Papers 173 


\section{KOF Working Papers}

Trying to Assess the Quality of Macroeconomic Data -

the Case of Swiss Labour Productivity Growth as an Example

Jochen Hartwig 


\section{KOF}

ETH Zurich

KOF Swiss Economic Institute WEH D 4

Weinbergstrasse 35

8092 Zurich

Switzerland

Phone +41446324239

Fax +4144 6321218

www.kof.ethz.ch

kof@kof.ethz.ch 


\title{
Trying to assess the quality of macroeconomic data - the case of Swiss labour productivity growth as an example
}

\author{
Jochen Hartwig \\ ETH Zurich, KOF Swiss Economic Institute*
}

\begin{abstract}
Macroeconomic data are indispensable for modern governance, yet it is often unclear how reliable these data are. The production process of macroeconomic data inside the statistical offices is often not very transparent for the general public. Bystanders usually have no choice but to take for granted the published data because criteria by which to judge data quality are wanting. Hoping to contribute to a better understanding of the quality of macroeconomic data, this paper proposes several plausibility checks and applies them to recently published Swiss labour productivity growth figures. Although the proposed checks cannot 'prove' or 'disprove' the official data, they are capable of either strengthening our confidence in the official data or, alternatively, of casting them into doubt. Policy debates drawing on official data will hardly be able to ignore differences in the degree of confidence with which these data are held to be accurate.
\end{abstract}

Keywords: $\quad$ Accuracy of macroeconomic observations, statistical artefacts, labour productivity

JEL classifications: $\quad \mathrm{C} 82, \mathrm{O} 47$

\footnotetext{
Address for correspondence: Jochen Hartwig, KOF ETH, WEH E7, Weinbergstr. 35, CH-8092 Zurich, Switzerland, hartwig@kof.ethz.ch.
} 


\section{Introduction}

As KENDRICK (1996: 1) points out, compilations of macroeconomic data have become "an indispensable tool for macroeconomic analysis, projections, and policy formulation." "By monitoring economic movements", he adds, "policy-making agencies including the central bank can see if they are on track with respect to national objectives regarding growth, price inflation, the trade balance, unemployment, and so on, and, if not, they can take appropriate actions" (1996: 4-5).

Yet, macroeconomic data are not only important domestically; also international comparisons are based on them. Economic country rankings seem to become evermore popular, and these have begun to exert a profound influence on society. Consider the empirical finding that the US outperforms continental Europe with respect to Gross Domestic Product (GDP) growth. This finding has spurred heated debates in many European countries on how to devise 'structural reforms' that would make the set-up of the respective economy more similar to how the US economy is perceived to be. Taxcutting, reducing the size of the public sector, and 'labour market reforms' (for instance, introducing a low-wage sector, curtailing the influence of trade unions, and increasing either weekly or lifetime working hours) are typical ingredients of this kind of debate, which is also promoted by international organizations such as the OECD, the IMF, and the WTO. Arguably, the main impact of macroeconomic data on governance can be found here.

So what about the quality of the data these policy debates are based on? Already MORGENSTERN (1950) cautioned against putting too much trust in macroeconomic data. Admittedly, much has been done since then to improve data quality. In 1953, the United Nations issued the first version of their System of National Accounts (SNA) aiming explicitly at harmonizing data collection and dissemination across countries (cf. UNITED NATIONS, 1953). The revised SNA 1968 (cf. UNITED NATIONS, 1968) integrated the production, distribution and appropriation accounts with financial accounts (or flowof-funds accounts, as they are called in the US). Not all countries saw themselves able, though, to devote enough resources to their statistical offices to arrive at the intended high degree of sophistication; and still others, like the US, preferred to stick to their own national income accounting rules that differed somewhat from the international 
standards (cf. MEAD ET AL., 2004). ${ }^{1}$ Nevertheless, in 1993, yet another version of the SNA was published (cf. INTER-SECRETARIAT WORKING GROUP ON NATIONAL ACCOUNTS, 1993), a new version that - although it did not introduce many major conceptual changes - once again raised the level of detail and thus the complexity of the system as a whole. By now, harmonization has come a long way in theory; yet substantial differences between national accounting practices remain - especially in the field of constructing deflators. HARTWIG (2006) illustrates such differences by a comparison between Switzerland and the US, and HARTWIG (2007) shows that a large part of the transatlantic gap in economic growth (between the US and the European Union) since the midnineties can be explained in terms of changes to deflation methods that have been introduced in the US after 1997, but not - or only to a very limited extent - in Europe.

The present paper goes beyond the problem of international differences in accounting practices to the fundamental layer of data production within the statistical offices. How do these offices arrive at their figures? This is a question that is sometimes very difficult to answer from outside the statistical offices, especially when it comes to macroeconomic data. Data on value added and employment, for instance, are collected in establishment and household surveys which often comprise only a small percentage of the respective populations. Neither does the general public know how serious the participants in these surveys take their task - and hence how reliable the answers are-, nor is it quite clear what methods are used to extrapolate the survey results to the macro level. All what the public gets to know are the bare figures that come out of the 'black box' of data production. But how good are these figures? Although this question cannot be answered conclusively, the plausibility of macroeconomic data may be scrutinized nevertheless. This paper will propose five kinds of plausibility checks for macrodata and apply them to recently released Swiss labour productivity growth figures.

\section{Swiss labour productivity growth - the official picture}

In order to measure labour productivity, several decisions have to be taken - first of all the decision how to measure production and labour input. The Swiss Federal Statistical Office (Bundesamt für Statistik, BFS) had to take these decisions in 2006 before the publication of its new labour productivity growth figures (in October). The Office

\footnotetext{
${ }^{1}$ The most fundamental difference is that the US National Income and Product Accounts (NIPAs) are calculated from the demand side - the GDP is the sum of demand-side components - while the SNA calculates GDP from the supply side as the difference between gross output and intermediate inputs.
} 
decided to identify the economy-wide production with the gross domestic product $(G D P)^{2}$ and to set the input of labour equal to total hours worked in the economy.

The Swiss GDP is calculated from the supply side. The most important data source is the 'Statistic on value added' (Wertschöpfungsstatistik, WS). The WS is an annual establishment survey among approximately 12'000 enterprises from the secondary and tertiary sectors. The sector finance and insurance is excluded; data on the value added of the financial industries as well as on agricultural services and the public sector are taken from other sources.

The results of the WS have to be extrapolated to the macro level. It is not exactly clear, however, how this is done. The most important indicator used for these extrapolations is presumably full-time equivalent employment coming from the 'Employment statistic' (Beschäftigungsstatistik, BESTA). The BESTA is a quarterly establishment survey among approximately $66^{\prime} 000$ enterprises from the secondary and tertiary sectors. One can use the 'Employment statistic' for extrapolations of value added to the macro level by assuming that under each industry classification title the share of the firms in the WS sample in value added is equal to their employment share in the BESTA. However, there are also people working outside establishments; and some think that such 'informal' employment is on the rise in Switzerland (cf. BALASTĖR/ SURCHAT, 2005). In this case, the extrapolation method just described would underestimate the (growth of) value added. Therefore, BFS officials have maintained (in personal communication) that they do not arrive at macro figures for value added by 'mechanically' extrapolating with BESTA employment shares. Rather, they claimed to use information from 'other' statistics so that the official value added figures would reflect the contributions of those 'irregularly' employed. How this adaptation is exactly done is not very transparent, however. It's far from obvious what information would enable the BFS to estimate the value added of those 'irregularly' employed and to distribute their contributions correctly over the branches of industry.

As mentioned before, the statistical offices also have to decide how to measure the input of labour in order to calculate productivity growth rates. Since October 2006, the BFS uses two different labour input measures. For the economy as a whole, BFS sets labour input equal to total hours worked. The main data source for total hours worked is the 'Swiss labour force survey' (Schweizerische Arbeitskräfteerhebung, SAKE), which is an annual household survey by telephone that was initiated in 1991. Until 2001, the

\footnotetext{
${ }^{2}$ DOMAR (1961) has argued in favour of identifying production with gross output instead of GDP for productivity measurement purposes.
} 
sample size was approximately 16 '0oo persons picked randomly from the telephone book. Afterwards, the sample was enlarged and today contains approximately 48'000 persons. The SAKE does not adequately document the hours lost due to strikes, shorttime work and lockouts; these data are taken from statistics prepared by the Swiss ministry for economic affairs (Secretariat d'Etat à l'économie, SECO). Also, the SAKE does not contain information about the labour input of foreign cross-border commuters, which is an important factor in Switzerland. The BFS prepares a special 'Commuter statistic' (Grenzgängerstatistik) from which the necessary information is drawn. Swiss labour productivity, so defined, has grown by just 1.1 percent per year on average over the period 1991 to 2004 (cf. Figure 1). This puts the country at the very bottom in international comparisons of labour productivity growth. ${ }^{3}$

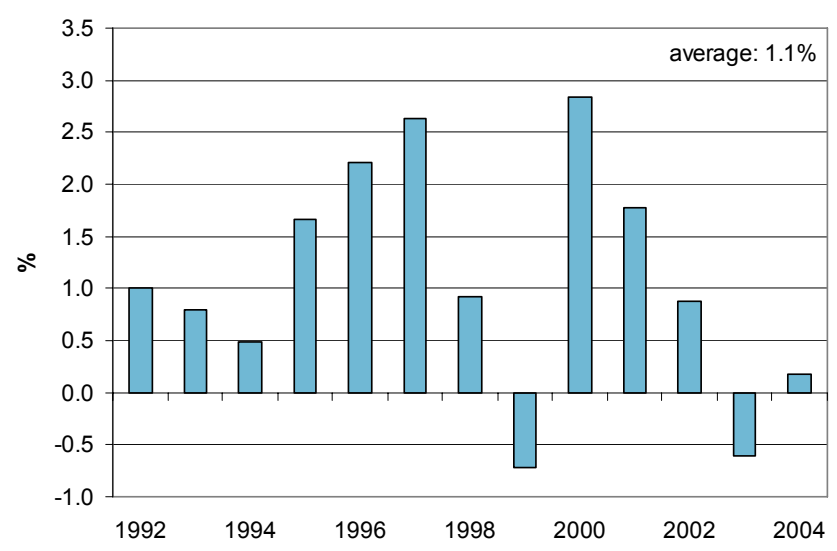

Figure 1: $\quad$ Swiss labour productivity growth (Source: BFS)

As mentioned above, a second measure of labour input is published in Switzerland, that is, full-time equivalents. The data sources for the calculation of these full-time equivalents are the same as for hours worked. The BFS relies mainly on the household survey SAKE and takes additional information - especially on the labour input of crossborder commuters - from other sources. This choice of data sources is new. Up to 2004, the BFS published different time series for the economy-wide and sectoral full-time equivalents which were then based on the establishment survey BESTA. The BESTAbased series - which covered the period 1992 to 2002 - were discontinued without much ado some time during 2004; and two years later, the new SAKE-based series were introduced. These currently cover the period 1991 to 2004.

The new full-time equivalents are used to calculate labour productivity growth for the branches of industry. The BFS publishes no series for the economy-wide full-time equivalents any more, only for what the office calls the 'Business sector'. In many

\footnotetext{
${ }^{3}$ Results of such comparisons with a focus on Switzerland can be found in BFS (2007).
} 
studies by international organisations (cf., for instance, WöLFL, 2005: 31, ECB, 2006: 52, 100ff.) the business sector is identified as comprising the industries 1 to 74 of the International Standard Industrial Classification (ISIC) scheme. ${ }^{4}$ This means that not only the public administration (ISIC 75) is excluded from the business sector, but also the 'personal services' education (ISIC 80) and health and social work (ISIC 85) and also the 'other' services (ISIC 90-95). HARTWIG (2006) has followed this practice. The BFS, on the other hand, defines the non-business sector more narrowly as comprising only ISIC 75including public education - and those parts of the services of ISIC 85-95 that are provided by 'non-profit institutions serving households' (NPISH). Renting of shelter by private households (including homeowners' rent equivalent, ISIC 96-97) is also excluded. No productivity figures are published for the non-business sector because here the production either takes place without labour input - as in the case of renting or because there are no market prices with which the value added could be measured. In the absence of market prices, value added is normally set equal to the value of the labour input so that productivity growth is automatically biased towards zero. In defining the business sector the way it does, the BFS follows the example of the US Bureau of Labor Statistics (BLS), cf. ELDRIDGE (1999). Contrary to the BLS, however, the Swiss statistical office does not refrain from publishing a productivity growth rate for the overall economy (besides the rate for the business sector).

Not only labour input, but also the numerator of the productivity ratio is defined somewhat differently at sectoral level as compared to the economy as a whole. The value of the sectoral output is defined as gross value added (GVA). The sum of gross value added of all sectors (including the non-business sector) differs from GDP in that it includes subsidies on products, but excludes taxes on products. Also, the value of the so-called financial intermediation services indirectly measured (FISIM), which represent banks' interest receipts less disbursements, is part of the gross value added of the banking sector, but currently does not enter the Swiss GDP (cf. HARTWIG, 2006).

Table 1 shows that when labour productivity is measured as aggregate gross value added per full-time equivalent, the average growth rate drops to 1.0 percentage points (PP) per year. The difference vis-à-vis the hourly-based measure stems from the nominator of the productivity ratio, though. Replacing gross value added by GDP increases the average growth rate to 1.1 PP again. If the average productivity growth rates based on hours worked and on full-time equivalents, respectively, are equal, this

\footnotetext{
${ }^{4}$ In Switzerland, this scheme is known as nomenclature générale des activités (NOGA).
} 
implies that the number of hours worked by those working full-time must have remained unchanged between 1991 and 2004. This can be checked with data from the Swiss 'Labour volume statistic' (Arbeitsvolumenstatistik, AVOL), for which, once again, the household survey SAKE is the main source. This statistic indeed shows that the number of hours worked by those working full-time has been around 1'930 hours both in 1991 and in 2004. Thus, both measures of labour input present a consistent picture of a very low average productivity growth in Switzerland of 1.1 percent per year. The next sections move on to the question how plausible such a low value is.

\begin{tabular}{ccc}
\multicolumn{2}{c}{ Average labour productivity growth rate in Switzerland, 1991-2004 } \\
\hline $\begin{array}{c}\text { Based on GDPper } \\
\text { hour worked }\end{array}$ & Based on GVA per & Based on GDP per \\
$\mathbf{1 . 1} \%$ p.a. & $\mathbf{1 . 0 \%}$ p.a. & full-time equivalent \\
\hline
\end{tabular}

Table 1: $\quad$ Swiss productivity growth according to different measures (Source: BFS, partly unpublished ${ }^{5}$ )

\section{The fading of Swiss productivity growth}

As mentioned above, the Swiss statistical office took information on labour inputs from the establishment survey BESTA, not from the household survey SAKE in earlier times. The main advantages of the BESTA vis-à-vis the SAKE are, first, that the frequency of the survey is higher (quarterly vs. annual), second, that the sample is larger (66'ooo units vs. 48'ooo units), and third, that it follows the so-called domestic concept which is also relevant for the calculation of GDP. This means that the BESTA includes foreign cross-border commuters who work in Switzerland and who contribute to Swiss GDP, whereas the SAKE only covers Swiss residents. A fourth advantage of the BESTA is its greater level of detail compared to the SAKE. The BESTA allows the Swiss statistical office BFS to collect labour input data down to the four digit level of the NOGA (the Swiss ISIC version). In contrast to this level of detail, respondents in the household survey SAKE can only give relatively crude information on which industry they work in.

\footnotetext{
${ }^{5}$ As mentioned above, the BFS does not publish full-time equivalents for the economy as a whole. However, full-time equivalents for the non-business sector are also calculated by the BFS for internal use and may be obtained from the office under the proviso not to publish them. This paper will respect this proviso and present only summary statistics that do not allow readers to infer numbers of full-time equivalents.
} 
However, the BESTA also features some disadvantages compared to the SAKE when it comes to presenting an accurate picture of labour input. Firstly, the BESTA excludes the sectors agriculture and private households (as producers). And secondly, it is known from the literature that establishment surveys like the BESTA tend to underestimate the number of unpaid overtime hours (cf. BRUYĖRE/CHAGNY, 2002: 5). ${ }^{6}$ It follows that the BESTA to some extent understates the level of employment.? Overall, it is clear that neither establishment nor household surveys present a totally accurate picture of labour input. Therefore, most statistical offices use a combination of both statistics to arrive at labour input data (cf. OECD, 2004). The Swiss office on the other hand has now chosen to rely entirely on the household survey SAKE.

BRUYĖRE/CHAGNY (2002), in their study of 8 OECD countries, find that in most of them labour input growth according to the household surveys exceeds its counterpart from the establishment surveys since the beginning of the nineties. Switzerland is no exception in this respect as Figure 2 shows. Therefore, it is clear that the switch from the establishment-based labour input measure to the one coming from the household survey, which the BFS performed in October 2006, must have lowered published labour productivity growth rates. Figure 3 affirms this. During the period for which comparable data is available (1992-2002), the productivity growth rate with the 'new' full-time equivalents based on the household survey as denominators has been lower than the old establishment-based rates in all years except 1999 and 2000. The difference in the average annual growth rate over the period 1992-2002 amounts to 0.57 percentage points (PP). This is an impressive figure, given that BRUYĖRE/CHAGNY (2002, table 2) estimate that a switch from labour input figures based on establishment surveys to figures based on household surveys would lower the average productivity growth rate by only 0.1 PP in Germany, France and Italy and by 0.3 PP in the US. The fact that the Swiss figure is almost twice as high as the highest estimate of Bruyère \& Chagny could indicate that there is something wrong with the new Swiss labour input measure. This will be checked in the next section.

\footnotetext{
${ }^{6}$ On the other hand, a study by the OECD (OECD, 1998) yielded that in France, Germany and Switzerland shorter absences due to illness or accidents at work are underestimated by $45-60$ percent in household surveys.

${ }^{7}$ With respect to employment trends, however, the resulting error is unimportant as long as employment in agriculture and private households or unpaid overtime does not grow (or decline) in importance. ABRAHAM ET AL. (1998: 314) "know of no hard evidence bearing on the level of such activity [off-the-clock work] or, more important, on its trend".
} 


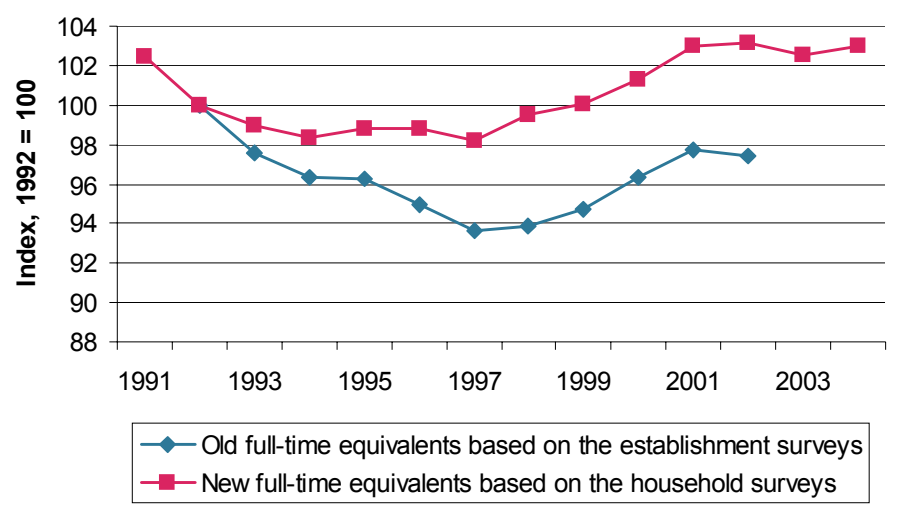

Figure 2: $\quad$ Different measures of labour input in Switzerland (Source: BFS, partly unpublished)

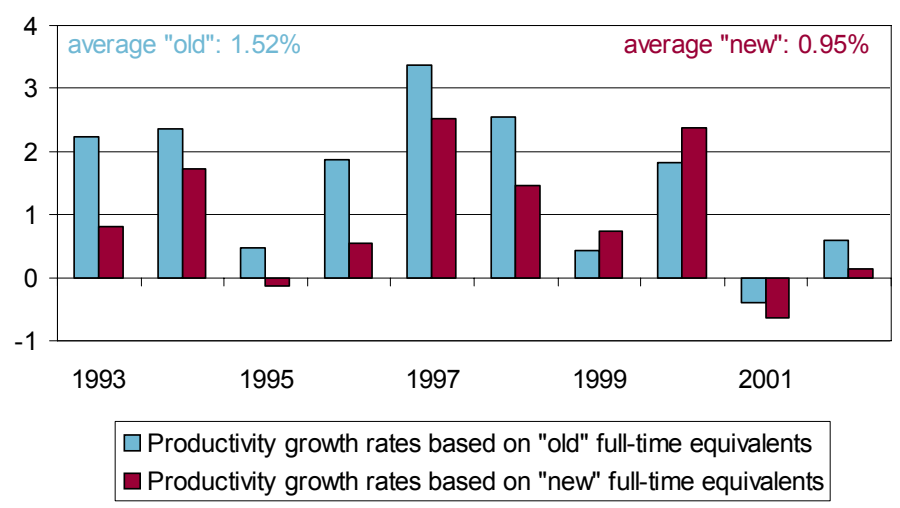

Figure 3: $\quad$ The decline of Swiss productivity growth after the switch to labour input measures based on household surveys (Source: BFS, partly unpublished)

\section{Checking the plausibility of the new Swiss labour input data}

The divergence of labour input series based on household surveys from those based on establishment surveys is a phenomenon that can be observed in many OECD economies; yet it is a phenomenon not well understood so far. Convinced that the new Swiss labour input series presents an impeccable image of de facto labour market developments, economists at the Swiss ministry of economic affairs (SECO) have jumped to the conclusion that the divergence figure 2 shows must be due to an increase of 'a-typical' or 'informal' employment relationships (not covered by the establishment survey) in recent times, such as telework, temporary employment, workon-demand, 'sham' self-employment or contracting-out (cf. BALASTÈR/SURCHAT, 2005: 4344, SECO, 2005: 48)..$^{8}$ It's far from obvious, however, why all these employment relations

\footnotetext{
${ }^{8}$ BALASTÈR/SURCHAT (2005: 43) also mention that the BESTA has problems capturing the employment at newly established firms because the latter are underrepresented in the sample. If young establishments grow more rapidly on average than older establishments - or if employees work longer hours there -,
} 
should escape the establishment survey BESTA. If the 'a-typical' employment takes place within establishments, then it should, in principle, be covered by the BESTA. Furthermore, while an increase in 'a-typical' employment might be a main driver behind the divergence between the series in countries with relatively inflexible labour markets (like Germany, for instance), it is questionable why Switzerland with its already very flexible labour market should have gained almost 200'000 'a-typical' full-time equivalents (amounting to 5.5 percent of total labour input according to the SAKE) between 1992 and 2002.9

There is an empirical finding, however, that speaks in favour of the hypothesis that the divergence between the two labour input series might be due to an increase in 'irregular' employment in the SECO sense. This finding is the sharp rise in selfemployment during the long stagnation of the Swiss economy in the nineties. In fulltime equivalents, the number of self-employed rose by almost 100'0oo between 1991 and 1998, 60 percent of which were women. ${ }^{\circ}$ While the number of male self-employed dropped sharply after 1998, the number of female self-employed remained relatively stable. It is probable that, during a recession, people who lose their jobs start their own businesses rather than being unemployed. Part of this new self-employment will be 'sham', that is, the self-employed person has no own firm, no employees and, as a rule, only one customer. Such jobs indeed escape the employment survey BESTA. Since it is known that (at least in Switzerland) 'sham' self-employment is more common among women than among men (cf. HöGLINGER, 2006: 29), the sustained rise in female selfemployment after 1991 could indeed point to an increase in 'irregular' employment.

employment growth according to the BESTA would be biased downward due to the underrepresentation of newly established firms in the sample. ABRAHAM ET AL. (1998: 314) maintain, however, that "there is no clear basis for having any particular prior expectation as to whether workers at younger establishments should work more or fewer hours than their counterparts at more established concerns". With respect to employment growth, ARVANITIS ET AL. (2004: 31) show on the basis of a comparison of successive establishment censuses that employment growth in established Swiss firms is typically higher than in firms newly entering the market. Thus - contrary to the SECO view - the underrepresentation of newly established firms in the BESTA sample should introduce a slight upward bias into BESTA employment growth rates.

9 The number of full-time equivalents has declined by approximately 85'000 between 1992 and 2002 according the 'old' BESTA-based series, while it has increased by around 107'000 according to the 'new' SAKE-based series.

${ }^{10}$ These figures are calculated based on data from the Swiss 'Labour volume statistic' (AVOL). 
Still, even if all of the increased self-employment of women after 1991 was 'sham', this could only explain around 20 percent of the divergence between the BESTA-based and SAKE-based labour input series. It is very improbable, of course, that there has been no 'regular' female self-employment. HÖGLINGER (2006: 28), in his pioneering study on 'atypical' employment in Switzerland, estimates that, in this country, there were overall just around 25'000 'sham' self-employed persons in 2003. He concludes (pp. 27-28) that temporary employment as well work-on-demand and 'sham' self-employment slightly increased during the nineties. Overall, however, Höglinger maintains that the relation between 'regular' and 'irregular' employment has remained fairly stable. ARVANITIS ET AL. (2002: 24) also point out that "(i)n sum, no spectacular changes have taken place in the Swiss labour market in the last fifteen years with respect to new types of quantitative flexibilization such as part-time jobbing, fix-term contracting, mediation of workers through manpower agencies and so on. The reason for the lack of great changes in terms of the above-mentioned numerical flexibility in the nineties is that the Swiss labour market has already being relative (sic!) flexible before the period of economic stagnation". It follows that the explanation for the divergence between the BESTAbased and SAKE-based labour input series that relies on an increase in 'irregular' employment remains without foundation.

An alternative explanation for the divergence between the two series would be an increased over-reporting of hours worked in the labour force survey." Intuitively, it seems plausible to assume that, say, factory workers should better be able to report their hours worked correctly than people with a more variable work content. MELLOW/SIDER (1983) were able to match data from establishment and labour force surveys so that workers' answers to questions about their working time could be compared with their employers' answers. It turned out that among workers paid by the hour, the hours reported by both parties were very close. Hours reported by managers and professionals, on the other hand, exceeded those reported by their employers by nearly 11 percent. Given that among managers and professionals there is "an ethic that says that good employees work more hours" (ABRAHAM ET AL., 1998: 316), the probability that managers and professionals over-report their hours is higher than the probability that their employers under-report them. The shift in the occupational mix away from manufacturing jobs and toward jobs with a more variable work content would thus lead to an increased over-reporting of hours worked in labour force surveys. Also, the

\footnotetext{
"Again, the fact alone that hours are over-reported would not explain the divergence between the two series.
} 
sharp rise in self-employment that occurred in Switzerland during the nineties has probably biased reported hours upward since "the self-employed could be more likely to inflate their working time because they might feel more responsible for their businesses, even when they are not technically at work" (JACOBS, 1998: 44).

Further evidence that the tendency to over-report hours worked has worsened over time is provided by HAMERMESH (1990) who compares individuals' answers to questions about their hours worked with their own entries in time diaries. Hamermesh conducted his study in 1975 and repeated it in 1981, being able to re-interview 80 percent of his subjects. He found that respondents over-reported their hours worked in both years compared to their diaries. But while the discrepancy was only 1.5 hours per week in 1975, it more than doubled to 3.6 hours in 1981. In a similar study, ROBINSON/BOSTROM (1994) reach similar conclusions. Taking time diary estimates for granted, they find that workers over-reported their average workweeks by one hour in 1965, by four hours in 1975, and by seven hours in 1985. Overall, the empirical evidence for the US suggests that increased over-reporting of hours worked in labour force surveys is the best candidate to explain the divergence of labour input measures based on establishment surveys and on household surveys, respectively. ${ }^{12}$ Therefore, establishment-based labour input measures - not being biased by over-reporting - have to be preferred over measures based on household surveys when it comes to calculating labour productivity growth. This statement carries over to Switzerland. The occupational mix shifts in the same direction as its US counterpart; therefore, an increased over-reporting of hours worked in the labour force survey SAKE must also be expected. This seems to be the best explanation available for the divergence between the BESTA-based and the SAKEbased labour input series. ${ }^{13}$

Empirical evidence also suggests that the new Swiss labour input series that relies on the household survey SAKE overstates true labour input growth. It is now time to

\footnotetext{
${ }^{12}$ Note that JACOBS (1998) suggests that the ROBINSON/BOSTROM (1994) findings may be due to a statistical artefact of regression to the mean. Jacobs here does not refer to Robinson \& Bostrom's average results, though, but to their additional finding that workers working long hours over-report their working time while those working few hours under-report it.

${ }^{13}$ If Switzerland indeed follows the US pattern, there is hope, however, that the divergence between the two labour input series might have become smaller recently. The OECD (2007: 41, panel F) shows that the discrepancy between the two measures - which is also observable in US data - reached its peak in the US around the turn of the century and is trending downward since then. The Organisation maintains at the same time (p. 40): "In general, the establishment survey is believed to be more accurate".
} 
introduce our first plausibility check, which questions the internal consistency of the labour force survey SAKE as a data source. The SAKE displays a marked increase in parttime employment in Switzerland over the last 15 years. The share of people working part-time (with an activity level of less than 90 percent) in the active population rose from 20 percent in 1991 to almost 30 percent in 2006 according to the SAKE. One would expect that this rise in part-time employment should have lowered the ratio between the number of FTEs and the size of the active population - as an average worker represents a smaller proportion of a full-time equivalent when part-time employment is on the rise. Figure 4 shows that the ratio indeed declines when calculated with the 'old' full-time equivalents (based on the establishment survey BESTA) as numerator. ${ }^{14}$ However, when calculated with the new SAKE-based FTEs as numerator, the ratio remains virtually unchanged, not reflecting the rise of the part-time employment share by 6.2 percentage points over the period 1992-2002. The only way for the ratio between FTEs and the active population to remain unchanged when part-time employment is rising is that there are shifts within the group of the part-time employed toward higher activity levels. Figure 5 shows, however, that there were no such shifts in Switzerland. The decline in the share of those working full time was accompanied by near-balanced rises in all other brackets except the one with the lowest activity level where the share remained constant. The drain from the brackets with low activity levels to the bracket with an activity level between 70 an 89 percent that would have been necessary to keep the ratio between FTEs and the active population constant did not occur. This implies that if we take the rise in part-time employment which the SAKE displays for granted, the new full-time equivalents (which are based on the same statistic) present a picture of an implausibly high labour input growth.

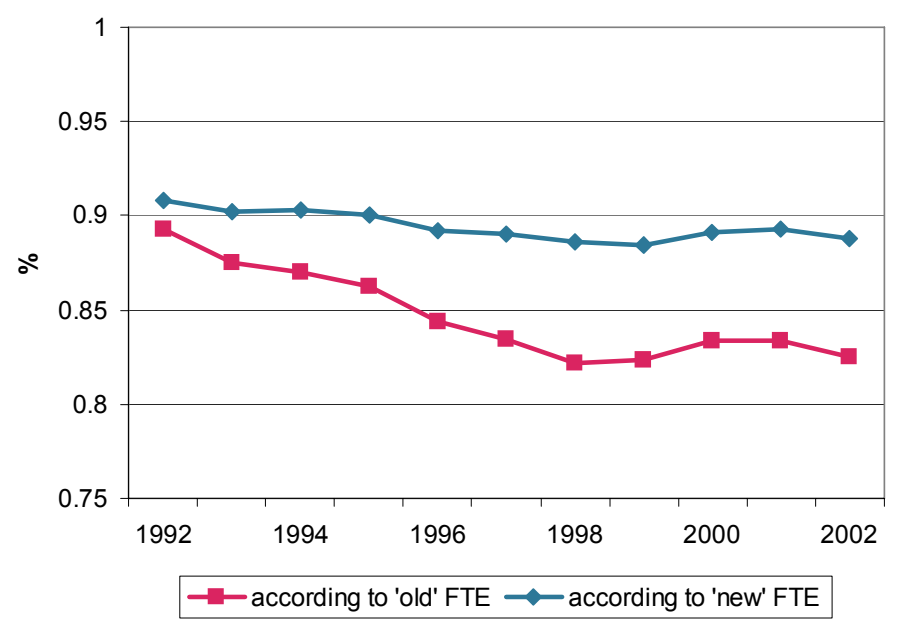

\footnotetext{
${ }^{14}$ Figure 4 confines itself to the period for which FTE data is available for both series, that is, 1992-2002.
} 
Figure 4: Ratio of the number of full-time equivalents to the size of the active population (Source: BFS, partly unpublished)

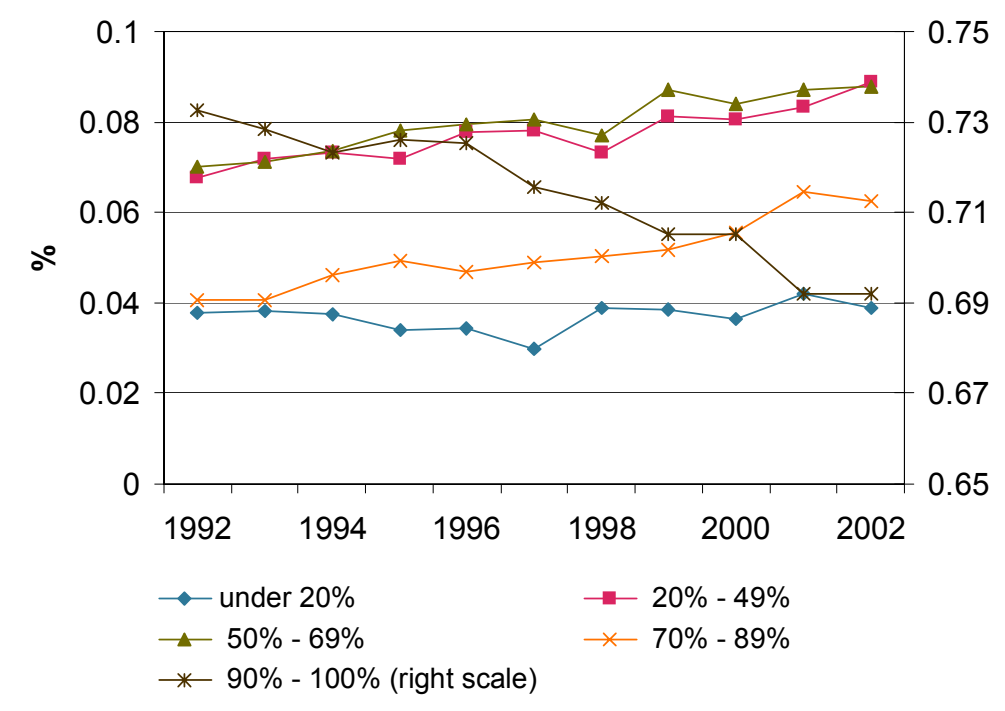

Figure 5: $\quad$ Employment shares sorted by activity level (Source: BFS)

A second way to check the plausibility of the new Swiss labour input series draws on wage data. The Swiss statistical office BFS publishes a wage index for the overall economy. This index is based on data from the 'Registration office for the statistics of the accident insurance' (Sammelstelle für die Statistik der Unfallversicherung, SSUV). Each year, over 300'000 people have an accident in Switzerland. Their insurance companies report (among other things) the wage level and the branch of industry of the casualties to the SSUV. The BFS draws on these data to calculate wage indices for the industries and the overall economy.

So calculated, the wage index does not reflect structural change in the economy. It reflects what, for instance, an average baker earns this year compared to the year before, but it does not recognize that people move on to better paid jobs or that the share of workers with higher qualifications is rising. Therefore, the wage index should normally grow less than the average per-capita compensation of employees. Data for the compensation of employees come from the central 'Old age insurance fund' (Altersund Hinterlassenenversicherung, AHV). In Switzerland, everybody is obliged to hold an insurance at the AHV so that the AHV statistic offers a full coverage of labour compensations. Therefore, it ranks among the most reliable Swiss statistics.

Clearly, the growth rate of average per-capita compensation of employees depends on which FTE series is used to calculate per-capita - or per full-time equivalent, to be precise - values. Figure 6 shows (as bars) the growth rates of labour compensation per 
full-time equivalent for three types of FTEs - the SAKE-based FTEs that the BFS now prepares for the National Accounts, the old BESTA-based FTEs that the BFS used to prepare for the National Accounts up to 2004, and, as the latter only cover the period 1992-2002, FTEs directly based on the BESTA. ${ }^{15}$ In addition to these, the growth rate of the wage index is shown as a line.

According to the old BESTA-based FTEs that the BFS used to prepare for the National Accounts, the per-capita compensation of employees outgrows the wage index in every year between 1992 and 2002. If the FTEs are taken from the BESTA directly, the compensation of employees outgrows the wage index in every year except 2003 where the growth rate of the wage index is slightly higher. According to the new SAKE-based FTEs that the BFS now prepares for the National Accounts, however, the wage index outgrows the compensation of employees in 1993, 1996, 1998, 2003 and $2004 .{ }^{16}$ The only explanation for this phenomenon other than an over-estimation of labour input would be that the qualification structure of the Swiss economy has deteriorated during these years. If workers, on average, move to jobs with lower pay, the wage index outgrows the per-capita compensation of employees. This, of course, seems to be a very implausible explanation.

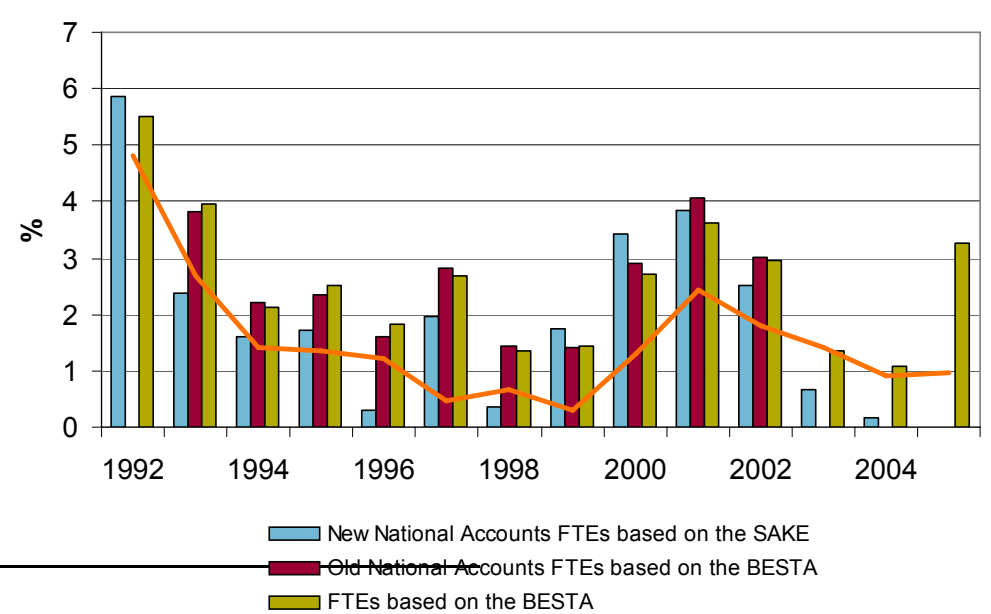

15 The difference betweres ither BESTA-based full-time equivalents formerly prepared for the National Accounts and the BESTA figures themselves is that the former include estimates for the FTEs in the sectors that the BESTA does not cover (agriculture, private households as producers). As can be inferred from figure 6 , the differences between the two series are very minor.

${ }^{16}$ The full-time equivalents in the denominator include the self-employed, whereas the compensation of employees (in the numerator) does not include their income. A correction can be made by calculating the number of FTEs of the self-employed based on data from the 'Labour volume statistic' AVOL and then deduct them from the denominator. This correction raises the growth rate of the compensation of employees per SAKE-based FTE above the rate of the wage index in 1998, but not in the other four years. The 2004 rate actually becomes negative. 
Figure 6: Growth of the wage index and of compensation of employees per fulltime equivalent (Source: BFS, partly unpublished)

To sum up, empirical evidence suggests that the labour input time series that BFS uses since the fall of 2006 to calculate labour productivity growth is upward-biased. Data from the establishment survey BESTA is better in line with the increasing trend towards part-time employment in Switzerland, and it offers a more plausible picture of the development of per-capita wages. As was shown in sections 1 and 2, the switch to the household survey-based full-time equivalents in 2006 has lowered the average labour productivity by more than 0.5 PP per year when production is measured as gross value added and by around 0.4 PP per year when production is measured as GDP. 0.4 PP is thus our best estimate of the downward-bias that the choice of the SAKE-based fulltime equivalents has introduced in the average Swiss labour productivity rate.

This statement can be corroborated by performing a so-called 'Slifman-Corrado correction'. CORRADO/SLIFMAN (1999: 330) find it "unlikely that firms with declining long term-productivity would be able to avoid bankruptcy, let alone maintain the rate of return to the owners". Yet, according to the new BFS data, long-term average annual productivity growth has been negative in 5 one-digit industries out of 14 , namely in ISIC A-B (Agriculture, hunting, forestry, and fishing), ISIC H (Hotels and restaurants), ISIC K (Real estate, renting and business services), ISIC M (Education), and ISIC O (Other community, social and personal service activities). Slifman and Corrado propose to assume a flat productivity growth instead of declining one for those industries.

Assuming zero productivity growth for the five industries mentioned and taking the new full-time equivalents for granted, alternative series for gross value added (GVA) can be calculated. Chaining all the 14 series - the alternative 5 and the unchanged 9 together gives an alternative series for overall GVA growth which can be used to calculate an alternative series for the GVA level at prices of an arbitrarily chosen reference year. Again taking the new full-time equivalents for granted, an alternative labour productivity series ensues. Table 2 shows that, on average over the period 1991 to 2004, the corrected productivity growth rate is by $0.41 \mathrm{PP}$ higher than the uncorrected one. This corroborates our earlier finding of a downward bias of around 0.4 PP in the official Swiss productivity growth data. 


\begin{tabular}{c|c|c}
\hline \multicolumn{2}{c}{ Average labour productivity growth rate in Switzerland, 1991-2004 } \\
\hline Based on GVA per & Based on GVA per & Difference \\
full-time equivalent & full-time equivalent & \\
before corrections & after corrections & \\
$0.95 \%$ p.a. & $\mathbf{1 . 3 6 \% \text { p.a. }}$ & 0.41 PP p.a. \\
\hline
\end{tabular}

Table 2: $\quad$ Swiss productivity growth before and after a 'Slifman-Corrado correction' (Sources: BFS, partly unpublished, and own calculations)

\section{Checking the plausibility of Swiss GDP data}

When the Swiss statistical office BFS introduced the new labour input data in the fall of 2006, it did not present new GDP or - for the sectoral levels - gross value added (GVA) figures at the same time. This means that in the 'production account' - being the first in the series of accounts that constitute the System of National Accounts (SNA) - the large changes in the labour input data did not affect output at all. The justification for treating input and output data as independent of each other was the Office's claim mentioned above in section 1 that the extrapolation of GVA and GDP figures from the 'Statistic on value added' sample - although it admittedly relied to a large extent on information coming from the establishment survey BESTA - was not done 'mechanically'. Rather, it allegedly included information from 'other' statistics so that the value added figures already reflected the contributions of those 'irregularly' employed - the latter allegedly constitute the difference between the BESTA and the SAKE figures, as will be remembered - even at a time (before 2004) when the full-time equivalents published in the National Accounts were based on the establishment survey alone. I leave it to the reader to assess the plausibility of this claim.

Given that the production process of macroeconomic data is not very transparent, sceptics might question the statistical office's claim that the GDP and GVA figures include the productive contributions of those 'irregularly' employed. As a matter of fact, until a couple of years ago, these contributions were largely unheard of, and, at any rate, they are hard to measure and to distribute correctly over the industries. If the value added of the 'irregularly' employed does not enter GDP and GVA, respectively, then the numerator and the denominator of the current official labour productivity measures are inconsistent; and the productivity growth rates are biased downward. The question is whether evidence exits that the Swiss GDP (growth) is downwardbiased. 
Such evidence indeed comes from an inspection of the Swiss wage share. In most developed countries, the wage share is currently declining. Table 3 lists the wage shares of the EU15 countries, the US, Japan, and Switzerland for 1980 and 2006. Obviously, the wage share has dropped in the vast majority of countries - sometimes by almost as much as ten percentage points. This finding is in line with economic theory, which suggests that globalization should have an adverse effect on the wage share in developed countries. The standard neo-classical Heckscher-Ohlin model, for instance, predicts that international trade increases the share of income going to labour in developing countries as labour is the abundant factor there. Consequently, as capital is abundant in developed countries, international trade, capital account liberalization and other related globalization phenomena should increase the share going to capital there. Non-orthodox theoretical approaches come to the same conclusion, albeit on different grounds. Authors such as CROTTY ET AL. (1998), RODRIK (1998), BURKE/EPSTEIN (2001), and HARRISON (2002) stress that due to the greater capital mobility brought about by globalization firms in rich countries are able to threaten workers with relocating production facilities to emerging economies. The reduced bargaining power of the factor labour results in a drop of the wage share. There is also a broad empirical literature which supports the idea of a falling wage share in developed countries (cf., for instance, Rodrik, 1998, Diwan, 2001, HarRison, 2002, Lee/JAYAdeV, 2005, Guscina, 2006).

\begin{tabular}{cccc}
\hline & 1980 & 2006 & Difference \\
\hline United States & 59.2 & 55.6 & $-3.6 \mathrm{PP}$ \\
Japan & 54.1 & 51.5 & $-2.6 \mathrm{PP}$ \\
Austria & 55.6 & 48.6 & $-7.0 \mathrm{PP}$ \\
Belgium & 57.0 & 50.3 & $-6.7 \mathrm{PP}$ \\
Denmark & 54.9 & 52.7 & $-2.2 \mathrm{PP}$ \\
Germany & $55.1^{1}$ & 49.7 & $-5.4 \mathrm{PP}$ \\
Greece & $32.3^{2}$ & 34.0 & $+1.7 \mathrm{PP}$ \\
Spain & 52.4 & 46.6 & $-5.8 \mathrm{PP}$ \\
France & 60.0 & 52.1 & $-7.9 \mathrm{PP}$ \\
Ireland & $46.3^{3}$ & 41.3 & $-6.0 \mathrm{PP}$ \\
Italy & 48.3 & 41.2 & $-7.1 \mathrm{PP}$ \\
Luxemburg & $54.3^{4}$ & 45.3 & $-9.0 \mathrm{PP}$ \\
Netherlands & 58.0 & 48.8 & $-9.2 \mathrm{PP}$ \\
Portugal & $47.4^{3}$ & 50.5 & $+3.1 \mathrm{PP}$ \\
Finland & 53.0 & 48.0 & $-5.0 \mathrm{PP}$ \\
Sweden & $54.9^{5}$ & 54.2 & $-0.7 \mathrm{PP}$
\end{tabular}




\begin{tabular}{cccc} 
United Kingdom & 59.8 & 55.6 & $-4.2 \mathrm{PP}$ \\
\hline Switzerland & 57.7 & $62.4^{6}$ & $+4.7 \mathrm{PP}$ \\
\hline
\end{tabular}

${ }^{1} 1991,{ }^{2} 1995,{ }^{3} 1990,{ }^{4} 1985,{ }^{5} 1993,{ }^{6} 2005$

Table 3: Wage shares for developed countries (compensation of employees as a share of GDP at market prices), in percent (Sources: Eurostat, for Switzerland: BFS)

Given that there are a priori reasons to believe that the wage share should drop in developed countries in the context of globalization - reasons that are validated empirically for most countries -, it is not unlikely that a measured increase in the wage share in countries such as Greece, Portugal, and Switzerland (cf. table 3) might have statistical causes. One such cause might be a shift in the tax system away from indirect taxation. If indirect taxes are reduced, GDP at market prices is lowered, and the wage share rises. Switzerland has very low indirect taxes which have not been raised as much as in other countries in recent years. So, in principle, it would be better to calculate the wage share not with GDP at market prices, but with GDP at basic prices as denominator. Unfortunately, data on GDP at basic prices are not available for all countries listed in table 3. Insofar as data exist, however, the wage share with GDP at basic prices as denominator presents the same picture of a rising Swiss share as opposed to dropping shares in most other countries. ${ }^{17}$ Shifts in the tax system thus cannot explain the peculiar development of the Swiss wage share.

Another characteristic of the Swiss economy that might have an impact on the wage share is the importance of the financial sector. Bankers' salaries - which enter the compensation of employees, i.e. the numerator of the wage share - are hardly affected adversely by globalization - more likely on the contrary. So the great weight of the banking sector in the Swiss economy might be a reason why the wage share rises just in this country. On closer inspection, however, it turns out that the wage share in financial enterprises has actually slightly declined since 1990 (cf. figure 7). This means that the contribution of the financial sector to the growth of the denominator of the wage share (GDP) is higher than to the growth of the numerator (compensation of employees). The importance of the financial sector for the Swiss economy thus also offers no explanation for the peculiar rise of the Swiss wage share.

\footnotetext{
${ }^{17}$ The low indirect taxes are partly responsible for the high level of the Swiss wage share, though. With GDP at basic prices as denominator, Denmark's and Sweden's wage shares are higher than Switzerland's.
} 


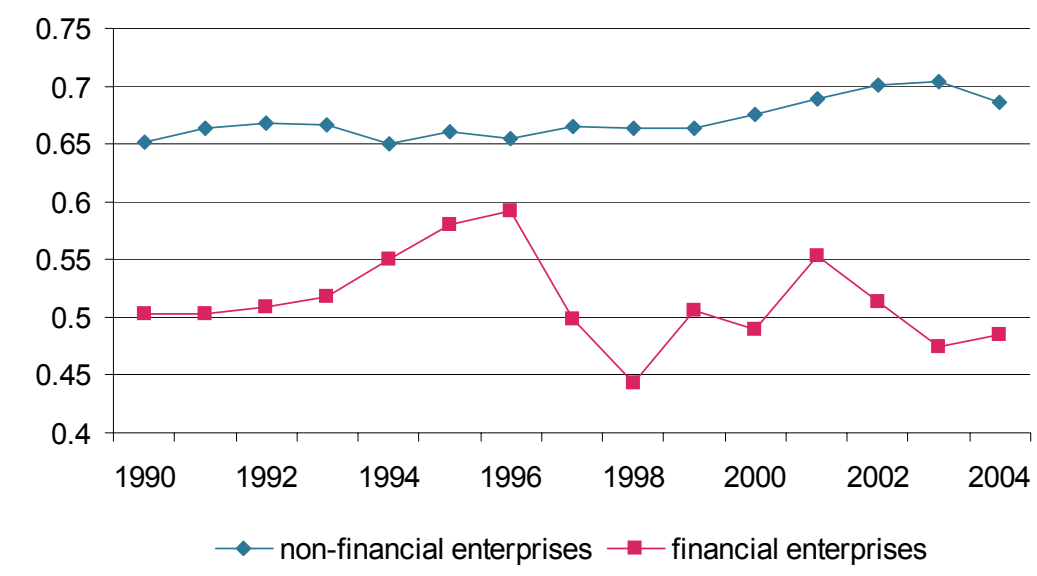

Figure 7: Wage shares in the financial and the non-financial sectors of the Swiss economy (Source: BFS)

So, is the rise of the Swiss wage share perhaps due to a pronounced militancy of Swiss workers? Everybody familiar with Swiss labour relations will reject this hypothesis immediately out of hand. HOTZ-HART ET AL. (1995: 69), for instance, point out: "The mentality and tenor of Swiss employees is basically consensus-oriented and trustful, surely not conflict-oriented. Mentally, employees have integrated to a large extent into the firms and with the employers" (own translation).

With a substantial explanation for the rise of the Swiss wage share wanting, we may conclude that this rise is the result of measurement error. As has been mentioned before, data for the numerator of the wage share, that is, compensation of employees, stem from a very reliable source. Therefore, the rise in the Swiss wage share is most likely due to an under-estimation of the growth of the denominator of that share, that is, GDP. If we assume that the wage share remained constant between 1980 and 2005 at 57.7 percent instead of rising, then nominal Swiss GDP in 2005 would have been higher by Fr. 37.5 bn. (or 8.2 percent) than according to the official figures. This implies that the average annual growth rate of nominal GDP over the period 1980 to 2005 would have been higher by 0.3 percentage points. (If the measurement problems pertain more to volumes than to prices, which is likely, real GDP growth would have been under-estimated to a similar extent.) Of course, if the Swiss wage share actually dropped - as was the case in most other countries -, the magnitude of the underestimation would be even greater.

A comparison of the growth rate of GDP with the growth rates of the demand-side components supports the idea that Swiss GDP growth might be under-estimated in official figures. The SNA prescribes that GDP should be calculated from the supply-side 
as gross production less intermediate inputs. The Swiss statistical office follows this rule. On the other hand, GDP could also be calculated as the sum of the demand-side components. This is the practice of Bureau of Economic Analysis which prepares the US NIPA tables. If one deducts the contributions to growth of the demand-side components (private and public consumption, gross fixed investment, and net exports) from the GDP growth rate as calculated from the supply side, one gets the contribution to growth of inventory investment. Figure 8 shows inventory investment's contribution to Swiss growth over the period 1981 to 2005 . Obviously, this contribution has been negative most of the time. On average over the period mentioned, inventory investment's contribution to growth has been -0.2 percentage points per year. This means that, on average, demand outgrows supply by 0.2 PP each year in Switzerland. The difference must be taken from inventories, which are thus more or less continuously depleted. True, an improved organisation of the production process has reduced the need for buffer stocks, which might explain why inventories are being reduced. Yet 'lean production' was in the media twenty years ago already. It is doubtful that it can explain why the contribution to growth of inventory investment has been negative in eight years out of ten over the last decade. More likely, the difference between supply and demand growth must be attributed to an under-estimation of the growth of supply, in other words, of GDP. The magnitude of the under-estimation of 0.2 PP per year roughly confirms our earlier estimate of 0.3 PP.

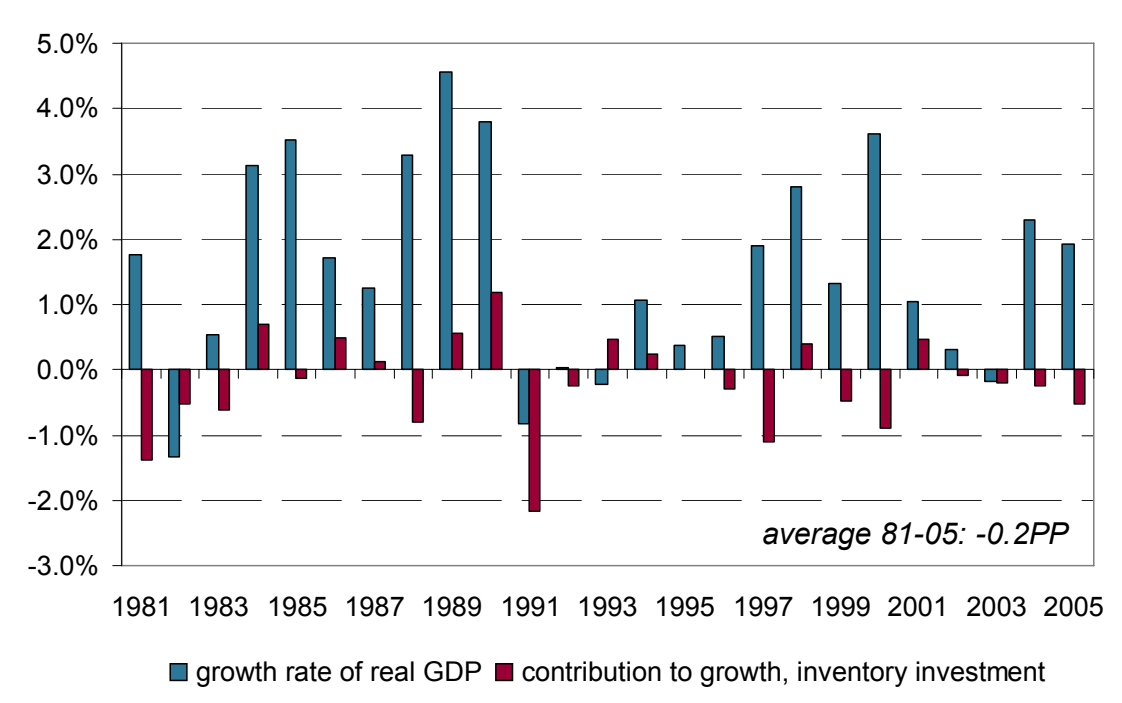

Figure 8: Inventory investment's contribution to growth in Switzerland (Source: BFS)

\section{Conclusion}


In many European countries, the seemingly better US growth performance since the mid-nineties (cf. GORDON, 2004) has spawned plans for reforms that would make the set-up of the respective economy more similar to how the US economy is perceived to be. Tax-cutting, reducing the size of the public sector, and 'labor market reforms' (e.g., introducing a low-wage sector, curtailing the influence of trade unions, and increasing either weekly or lifetime working hours) are typical ingredients of such reform plans. The point this paper makes against the backdrop of these policy debates is that it is essential to first scrutinize official macroeconomic data before drawing far-reaching policy conclusion from them. Even though the production process of macrodata is often not transparent for people outside the statistical offices, the plausibility of these data can be checked. This is here shown by the example of Swiss labour productivity growth figures.

The paper proposes five kinds of plausibility checks for these figures. The first check draws on the fact that part-time employment has strongly increased in Switzerland since the beginning of the nineties. It is argued that this should have led to a reduction in the ratio of the number of full-time equivalents (FTEs) to the size of the active population unless shifts within the group of the part-time employed toward higher activity levels could have been observed. Since neither these shifts nor a reduction in the ratio have occurred when it is calculated with the official full-time equivalents as numerator, the plausibility of the FTE series is impaired. Apparently, this series overreports (the growth of) labour input in Switzerland. This conclusion is supported by a comparison of wage growth according to the wage index on the one hand and according to the compensation of employees per full-time equivalent on the other. This is the second plausibility check the paper proposes. Since the wage index ignores wage increases due to structural change in the economy, it should normally grow less then the per-capita compensation of employees. With the official full-time equivalents as denominator, however, the wage index outgrows per-capita labour compensation in 5 years out of 14 over the period 1992-2005. This is not the case when the 'old' FTEs (published up to 2004) - which were based on an establishment survey rather than on a household survey which now serves as data source for labour input in Switzerland are used in the calculation of per-capita values. A comparison between the two different labour input series suggests that the average annual Swiss labour productivity growth rate might be downward-biased by around 0.4 percentage points due to the upward-bias in the official labour input (growth) measure. This figure is 
corroborated by a so-called Slifman-Corrado correction of the sectoral productivity growth rates (the third plausibility check proposed in the paper).

The final two plausibility checks address Swiss GDP data. Economic theory predicts that in developed countries the wage share should decline in the context of globalization. In line with theory, the wage share is indeed falling in most rich countries. In Switzerland, however, the wage share is on the rise. As data for the numerator of the wage share, that is, compensation of employees, stem from a very reliable source, the peculiar rise of the Swiss wage share is likely due to an underestimation of the growth of the denominator of the share, that is, GDP. If the Swiss wage share actually remained constant between 1980 and 2005 instead of rising, the average annual GDP growth rate would have been higher by 0.3 percentage points. A comparison of GDP growth with the growth contributions of the demand-side components - the final plausibility check the paper proposes -, which reveals a more or less continuous depletion of Swiss inventories, points to a similar figure for the underestimation of GDP growth.

According to official statistics, labour productivity in Switzerland grows by just 1.1 percent per year on average. The plausibility checks presented in this paper suggest, however, that the actual growth rate more likely lies in the range of 1.7-1.8 percent. This means that the shortfall of Swiss productivity growth against its US counterpart which is currently believed to be 1.2 percentage points per year - would narrow down to around half a percentage point. ${ }^{18}$

\section{References}

Abraham, K. G., Speltzer, J. R., Stewart, J. C. (1998): Divergent trends in alternative wage series, in: Haltiwanger, J., Manser, M. E., Tople, R. (eds.): Labor Statistic Measurement Issues, Chicago: University of Chicago Press, pp. 293-324.

Arvanitis, S., Hollenstein, H., Marmet, D. (2002): Numerical or functional flexibility: What is at stake for the Swiss economy?, KOF Working Paper, No. 64.

Arvanitis, S., Sydow, N., Wörter, M. (2004): Die Beschäftigungsentwicklung in der Schweiz 1985-2001 - Analysen zur Betriebszählung 2001, Neuchâtel, Bundesamt für Statistik. Balastèr, P., Surchat, M. (2004): Zur Produktivitätsentwicklung der Schweiz in den Neunzigerjahren: Wie schwach war sie wirklich?, Die Volkswirtschaft. Magazin für Wirtschaftspolitik, No. 8, pp. 43-45.

\footnotetext{
${ }^{18}$ The Bureau of Labor Statistics currently publishes an annual labour productivity growth rate of 2.3 percent (averaged over the past 15 years) for the US, cf. http://www.bls.gov.
} 
BFS [Bundesamt für Statistik] (2007): Strukturelle Analyse der Schweizer Wirtschaft. Wachstumsrate des BIP und des BNE pro Einwohner von 1991 bis 2003, Neuchâtel.

Bruyère, M., Chagny, O. (2002): The fragility of international comparisons of employment and hours worked. An attempt to reduce data heterogeneity, Observatoire français des conjunctures économiques, Working Paper, No. 05/2002.

Burke, J., Epstein, G. (2001): Threat effects and the internationalization of production, Political Economy Research Institute Working Papers, No. 15.

Corrado, C., Slifman, L. (1999): Decomposition of productivity and unit costs, American Economic Review, Vol. 82:2, pp. 328-332.

Crotty, J., Epstein. G., Kelly, P. (1998): Multinational corporations in the neoliberal regime, in: Baker D., Epstein G., Pollin R. (eds.): Globalization and Progressive Economic Policy, Cambridge: Cambridge University Press, pp. 117-143.

Diwan, I. (2001): Debt as sweat: Labor, financial crises, and the globalization of capital, mimeo, The World Bank.

Domar, E. D. (1961): On the measurement of technological change, Economic Journal, Vol. 71:4, pp. 709-729.

ECB (2006): Competition, productivity and prices in the Euro area services sector, European Central Bank Occasional Paper Series, No. 44.

Eldridge, L. P. (1999): How price indexes affect BLS productivity measures, Monthly Labor Review, February, pp. 35-46.

Gordon, R. J. (2004): Why was Europe left at the station when America's productivity locomotive departed?, NBER Working Paper, No. 10661.

Guscina, A. (2006): Effects of globalization on labor's share in National Income, IMF Working Paper 06/294.

Hamermesh, D. S. (1990): Shirking or productive schmoozing: wages and the allocation of time at work, Industrial and Labor Relations Review, Vol. 43: special issue, pp. 121S$133 \mathrm{~S}$.

Harrison, A. E. (2002): Has globalization eroded labor's share? Some cross-country evidence, mimeo, UC Berkeley.

Hartwig, J. (2006): Messprobleme bei der Ermittlung des Wachstums der Arbeitsproduktivität - dargestellt anhand eines Vergleichs der Schweiz mit den USA, Jahrbücher für Nationalökonomie und Statistik, Vol. 226:4, pp. 418-435.

Hartwig, J (2007): Is the transatlantic gap in economic growth really widening?, in: McCombie, J., Rodriguez, C. (Eds): The European Union: Current Problems and Prospects, Basingstoke: Palgrave-Macmillan, pp. 68-83. 
Höglinger, M. (2006): Schöne neue Arbeitswelt? Flexibilisierung der Arbeit durch atypische Arbeitsverhältnisse, soz:mag - Das Soziologie Magazin, No. 9/2006, pp. 2630.

Hotz-Hart, B., Mäder, S., Vock, P. (1995): Volkswirtschaft der Schweiz, Zürich: vdf Hochschulverlag.

Inter-Secretariat Working Group on National Accounts (1993): System of National Accounts 1993, Commission of the European Communities/Eurostat, International Monetary Fund, Organisation for Economic Co-operation and Development, United Nations, World Bank, Brussels/Luxembourg.

Jacobs, J. A. (1998): Measuring time at work: are self-reports accurate?, Monthly Labor Review, December, pp. 42-53.

Kendrick, J. W. (1996): Introduction and overview, in: Kendrick, J. W. (Ed): The New System of National Accounts, Boston: Kluwer Academic Publishers, pp. 1-23.

Lee, K., Jayadev, A. (2005): The effects of capital account liberalization on growth and the labor share of income: reviewing and extending the cross-country evidence, in: Epstein, G. (ed.): Capital Flight and Capital Controls in Developing Countries, Cheltenham: Edward Elgar.

Morgenstern, O. (1950): On the Accuracy of Economic Observations, Princeton, NJ: Princeton University Press.

Mead, C. I., Moses, K. E., Moulton, B. R. (2004): The NIPAs and the System of National Accounts, Survey of Current Business, December, pp. 17-32.

Mellow, W., Sider, H. (1983): Accuracy of response in labor market surveys: evidence and implications, Journal of Labor Economics, Vol. 1:4, pp. 331-344.

OECD (1998): Annual hours of work: definitional and comparability issues, Working Party on Employment and Unemployment Statistics, DEELSA/ELSA/WP7.

OECD (2004): OECD measures of total hours worked, mimeo (http://www.oecd.org/dataoecd/30/41/29867131.pdf).

OECD (2007): United States, OECD Economic Surveys, Vol. 2007/og.

Robinson, J. P., Bostrom, A. (1994): The overestimated workweek? What time diary measures suggest, Monthly Labor Review, August, pp. 11-23.

Rodrik, D. (1998): Capital mobility and labor, mimeo, Harvard University .

SECO [Secretariat d'Etat à l'économie] (2005): Die Berechnung der Arbeitsproduktivität in der Schweiz, Konjunkturtendenzen, Herbst, pp. 40-48.

United Nations (1953): A System of National Accounts and Supporting Tables. Studies in Methods, Series F, No. 2, United Nations, New York. 
United Nations (1968): A System of National Accounts. Studies in Methods, Series F, No. 2, Rev. 3, United Nations, New York.

Wölfl, A. (2005): The service economy in OECD countries, OECD - STI Working Paper $2005 / 3$. 